\title{
A Review on Applications of Remote Sensing and Geographic Information Systems (GIS) in Water Resources and Flood Risk Management
}

\author{
Xianwei Wang ${ }^{1, *}$ and Hongjie Xie ${ }^{2, *(1)}$ \\ 1 School of Geography and Planning, and Guangdong Key Laboratory for Urbanization and Geo-Simulation, \\ Sun Yat-Sen University, Guangzhou 510275, China \\ 2 Department of Geological Sciences, University of Texas at San Antonio, San Antonio, TX 78249, USA \\ * Correspondence: wangxw8@mail.sysu.edu.cn (X.W.); hongjie.xie@utsa.edu (H.X.); \\ Tel.: +86-20-84114623 (X.W.); +1-210-458-5445 (H.X.)
}

Received: 4 April 2018; Accepted: 3 May 2018; Published: 7 May 2018

\begin{abstract}
Water is one of the most critical natural resources that maintain the ecosystem and support people's daily life. Pressures on water resources and disaster management are rising primarily due to the unequal spatial and temporal distribution of water resources and pollution, and also partially due to our poor knowledge about the distribution of water resources and poor management of their usage. Remote sensing provides critical data for mapping water resources, measuring hydrological fluxes, monitoring drought and flooding inundation, while geographic information systems (GIS) provide the best tools for water resources, drought and flood risk management. This special issue presents the best practices, cutting-edge technologies and applications of remote sensing, GIS and hydrological models for water resource mapping, satellite rainfall measurements, runoff simulation, water body and flood inundation mapping, and risk management. The latest technologies applied include 3D surface model analysis and visualization of glaciers, unmanned aerial vehicle (UAV) video image classification for turfgrass mapping and irrigation planning, ground penetration radar for soil moisture estimation, the Tropical Rainfall Measuring Mission (TRMM) and the Global Precipitation Measurement (GPM) satellite rainfall measurements, storm hyetography analysis, rainfall runoff and urban flooding simulation, and satellite radar and optical image classification for urban water bodies and flooding inundation. The application of those technologies is expected to greatly relieve the pressures on water resources and allow better mitigation of and adaptation to the disastrous impact of droughts and flooding.
\end{abstract}

Keywords: remote sensing; geographic information systems (GIS); glaciers; water body; soil moisture; groundwater; flooding; rainfall measurements; design storm; runoff simulation

\section{Introduction}

Human-accessible freshwater resources primarily include mountain glaciers, snow, surface water bodies (lakes, rivers and reservoirs), soil moisture and ground water. Since they have very unequal distribution spatially and temporally, pressures on water resources are increasing globally. On the other hand, people may not know where and how much water resources are available regionally, especially for the remote mountain glaciers/snow, and deep confined groundwater. In extreme cases, if there is too little or too much water within a certain period and area, severe drought and torrent flooding could occur, often resulting in catastrophic impacts and damages to the local and regional community. Therefore, it is of great significance to map and manage water resources, drought and flooding risk precisely by using the cutting-edge technologies of remote sensing, geographic information systems (GIS), geostatistics and hydrologic models (Table 1). 
Table 1. Latest remote sensing technology and sensors used for water resources, hydrological fluxes, drought and flood mapping.

\begin{tabular}{|c|c|c|}
\hline Application Fields & Specific Contents & Examples of Sensors or Satellites \\
\hline \multirow[b]{2}{*}{ Water resources } & Snow & $\begin{array}{c}\text { AVHRR, Terra/Aqua MODIS, Landsat, SSM/I, } \\
\text { AMSR-E, Cryosat etc. }\end{array}$ \\
\hline & $\begin{array}{c}\text { Glaciers } \\
\text { Soil moisture } \\
\text { Groundwater } \\
\text { Lakes, reservoirs, rivers, and wetlands }\end{array}$ & $\begin{array}{c}\text { Landsat, ASTER, SPOT, ICESat, SRTM, etc. } \\
\text { SSM/I, AMSR-E, SMAP, SMOS, etc. } \\
\text { GRACE } \\
\text { MODIS, Landsat, SPOT, ICESat, GRACE, SRTM etc. }\end{array}$ \\
\hline Hydrological fluxes & $\begin{array}{c}\text { Precipitation } \\
\text { Evapotranspiration } \\
\text { River, reservoir or lake discharge }\end{array}$ & $\begin{array}{c}\text { NEXRAD, TRMM, GPM, etc. } \\
\text { MODIS, Landsat, GRACE, etc. } \\
\text { MODIS, ENVISAT, Landsat, SRTM, ICESat, etc. }\end{array}$ \\
\hline Drought and flooding & Drought and flooding & $\begin{array}{l}\text { MODIS, Landsat, GRACE, UAV, AMSR-E, SMAP, } \\
\text { SMOS, ENVISAT, ASAR, Sentinel-1A/2A, etc. }\end{array}$ \\
\hline
\end{tabular}

Remote sensing provides critical data for water resource mapping (Table 1). Satellite remote sensing techniques can make continuous and up-to-date measurements with global coverage depending on their orbital features, while they count on ground observations for algorithm development and validation [1]. For example, the Moderate Resolution Imaging Spectroradiometer (MODIS) on-board on Terra and Aqua satellites has provided daily global snow cover products since February 2000 [2]. They have been widely applied in different fields, such as hydrology, agriculture and climate studies [3,4]. Relative high-resolution images from the Landsat series could be used to recovery and monitor the global state of mountain glaciers, thus making it possible to update the global glacier inventories at high accuracy and confidence, such as the Global Land Ice Measurements from Space (GLIMS), and Glacier Area Mapping for Discharge from the Asian Mountains (GAMDAM), and the second Chinese Glacier Inventory [5-7]. Besides areas, glaciers surface elevation information extracted from satellite instruments of the National Aeronautics and Space Administration (NASA) Ice, Cloud and land Elevation Satellite (ICESat), Shuttle Radar Topographic Mission (SRTM), Advanced Spaceborne Thermal Emission and Reflection Radiometer (ASTER), SPOT 5 and even airborne stereo images were used to investigate glaciers' thickness and volume changes in the vast, high Asia Mountains [8-10]. MODIS images and ICESat elevation data were used together to map the lake water body areas and surface elevation changes in human-inaccessible regions in the Tibetan Plateaus for the first times on record [11,12]. The Advanced Microwave Scanning Radiometer for NASA's Earth Observing System (AMSR-E), NASA's Soil Moisture Active and Passive (SMAP) mission, and the European Space Agency (ESA) Soil Moisture Ocean Salinity (SMOS) mission all can provide global soil moisture mapping [1,13]. Groundwater is the most difficult to detect by satellite sensors, while the Gravity Recovery and Climate Experiment (GRACE) has been successfully used to measure groundwater depletion and the filling of the Three Gorges Reservoir [14,15]. Ground penetration radar can even obtain accurate estimations of glacier thickness, soil moisture, and groundwater [16,17].

Besides water resource mapping, remote sensing can also quantitatively measure hydrological fluxes, such as precipitation, evapotranspiration, river stages and discharges (Table 1). Ground-based radar such as the US Next Generation Weather Radar (NEXRAD) has been used to quantitatively measure precipitation on US territory since 1990s at relatively high accuracy, and has been widely applied to monitoring precipitation locally and regionally worldwide [18,19]. The Tropical Rainfall Measuring Mission (TRMM) was the first satellite to measure the global mid-latitude precipitation at unprecedented $0.25^{\circ}$ and 3-h product since 1998, e.g., the Multi-satellite Precipitation Analysis (TMPA), and the Global Precipitation Measurement (GPM) products have even been able to provide global near-real time precipitation estimates of $0.1^{\circ}$ and 30-min products since 2014, e.g., the Integrated Multi-satellitE Retrievals of GPM (IMERG) [20,21]. Those precipitation products greatly improve hydrological simulation and flood prediction due to their large coverage and relatively high spatial resolution [22]. Evapotranspiration (ET) can be estimated based on the Surface Energy Balance 
Algorithms for Land (SEBAL) using the radiance detected by satellite sensors, such as Landsat and MODIS retrievals [23]. Now, more energy balance-based models have been developed to estimate the field actual ET in agricultural management [24]. Together with in situ lake water level observations, daily MODIS images were also used to map the Poyang Lake's water volume and lake bed topography changes by the elevation contours derived from the land-water boundary line [25]. River discharge estimation was traditionally done by in situ observations, and now can also be detected by the synthetic width/stage-discharge rating curves via measuring the river's effective wet width and water level using MODIS, the Environmental Satellite (ENVISAT), Landsat and other high-resolution images [26-28].

Remote sensing techniques are playing increasingly important roles in drought monitoring and flooding emergency response (Table 1). Many drought indices were developed using MODIS reflectance data under different climate and land cover conditions, such as the Normalized Difference of Vegetation Index (NDVI), Normalized Difference of Water Index (NDWI), Visible Atmospherically Resistant Index (VARI), Enhanced Vegetation Index (EVI), Normalized Difference Infrared Index Band 6 or Band7 (NDIIB6/7), and so on [29-31]. Emerging Unmanned Aerial Vehicles (UAV) provide a more flexible low-altitude platform to monitor vegetation growth, soil moisture conditions, flood inundation mapping and damage assessment [32]. Flood mapping from various data sources can greatly improve disaster response, e.g., for the widespread and sustained flood events in several river basins in Texas and Oklahoma of USA in late April and May 2015, a total 27,174 space- and airborne images were applied to monitor the daily variations of flood inundation extents [33].

GIS is very versatile, especially in spatial analysis, modeling, visualization, data processing and management. At most times e.g., in this special issue, GIS operates heroically behind the scenes. Almost every paper published in this special issue uses GIS for data preprocessing, spatial analysis or establishing results maps (Table 2). With unprecedented data resources, it is quite challenging to manage so much data in risk management and especially in disaster response, such as in the aforementioned 2015 Texas flooding event. Schumann et al. [33] suggest that the proactive assimilation of methodologies and tools into the mandated agencies are required in order to unlock the full potential of those various data. GIS, such as the most popular ArcGIS products and other commercial or open source software, are required to process the original remote sensing images and videos, and carry out spatial analysis, modeling and visualization. Meanwhile, statistics can draw solid conclusions from the satellite images data and GIS spatial analysis.

Hydrologic models can take full use of the remote sensing and GIS data and carry out lots of physical experiments and scenario analyses. They are able to provide a full spectrum of modeling what happened in the past and project what will happen in the future. The availability of model simulations over a long time period also allows for a robust estimate of low-probability events that were not recorded in ground observations [34]. This is especially so for the remote and mountainous areas where there are few or even none in situ observations for rainfall and stream flows; satellite-measured rainfall is normally used to drive a hydrological model to simulate historical flooding events, thus projecting current and future flooding risk [35].

In summary, remote sensing techniques have played increasingly important roles in the hydrologic community (Table 1). They can map the spatial and temporal distributions of water resources, quantitatively measure the hydrologic flux, and monitor the working conditions of hydraulic infrastructures, drought conditions and flooding inundation. GIS, statistics and numerical models together can unlock the potential of various remote sensing data resources, and make for better management of water resources, drought and flooding disasters. The following session 2 summarizes the 12 papers published in this special issue (Table 2), which present the best practices, cutting-edge technologies and applications of remote sensing, GIS and hydrological models for water resources mapping, satellite rainfall measurements, storm hyetography analysis, runoff and urban flooding simulation, water body and flooding inundation mapping, and risk management. 
Table 2. Latest geographic information systems (GIS) and remote sensing technologies and hydrologic models applied in the 12 papers published in this special issue.

\begin{tabular}{|c|c|c|c|}
\hline Application Fields & Specific Contents & $\begin{array}{l}\text { GIS, Algorithm, Model, } \\
\text { Sensor or Satellites }\end{array}$ & Reference \\
\hline \multirow{4}{*}{$\begin{array}{l}\text { Water resources } \\
\text { mapping and } \\
\text { management }\end{array}$} & Glaciers mapping & $\begin{array}{l}\text { Landsat, ASTER GDEM, GIS, } \\
\text { TIN 3D model. }\end{array}$ & {$[36]$} \\
\hline & Soil moisture detection & $\begin{array}{l}\text { GPR, CMP, FO, GIS spatial } \\
\text { analysis }\end{array}$ & [16] \\
\hline & $\begin{array}{l}\text { Groundwater and } \\
\text { subsidence analysis }\end{array}$ & GIS spatial analysis, GPS & [37] \\
\hline & Irrigation planning & $\begin{array}{c}\text { UAV, HTM for video image } \\
\text { classification, GIS } \\
\text { visualization }\end{array}$ & {$[32]$} \\
\hline \multirow{2}{*}{$\begin{array}{l}\text { Rainfall } \\
\text { measurements and } \\
\text { design storm }\end{array}$} & Rainfall measurements & $\begin{array}{l}\text { TRMM, GPM, GIS spatial } \\
\text { analysis and visualization }\end{array}$ & [38] \\
\hline & $\begin{array}{l}\text { Design storm and urban } \\
\text { flood modeling }\end{array}$ & $\begin{array}{l}\text { Huff curve, SWMM, GIS data } \\
\text { preprocess and visualization }\end{array}$ & {$[39]$} \\
\hline \multirow{3}{*}{$\begin{array}{l}\text { Rainfall runoff } \\
\text { prediction and flood } \\
\text { forecasting }\end{array}$} & Flood modeling & $\begin{array}{c}\text { GSSHA model, GPM IMERG, } \\
\text { GIS visualization }\end{array}$ & {$[40]$} \\
\hline & Rainfall Runoff simulation & $\begin{array}{l}\text { RCM, LSM, CoLM, CoLM+LF, } \\
\text { GIS data preprocess }\end{array}$ & [41] \\
\hline & Flood inundation forecast & $\begin{array}{c}\text { ARX regressor, MOGA } \\
\text { algorithm, GIS visualization }\end{array}$ & [42] \\
\hline \multirow{3}{*}{$\begin{array}{l}\text { Water body and flood } \\
\text { mapping }\end{array}$} & Flash flood detection & $\begin{array}{l}\text { TMPA real time 3B2RT, CT, } \\
\text { CDFs, JFI, GIS spatial analysis }\end{array}$ & [43] \\
\hline & Urban water body mapping & $\begin{array}{l}\text { ZY-3 images, AUWEM, GIS } \\
\text { spatial analysis }\end{array}$ & [44] \\
\hline & Flood inundation mapping & $\begin{array}{c}\text { ENVISAT, ASAR, GIS spatial } \\
\text { analysis }\end{array}$ & {$[45]$} \\
\hline
\end{tabular}

\section{Summary of This Special Issue}

\subsection{Water Resources Mapping and Management}

Mountain glaciers and snow in the Tianshan Mountains are critical water resources in arid and semi-arid Central Asia [46]. Glacier areas are defined as the extent in two horizontal dimensions (2D area) in the ice mass balance community [47], and often used to estimate the total ice volume by volume-area power law equations [48]. In the high Tianshan Mountains, most glaciers lie on steep slopes, and their actual surface extent (3D area) may be much larger than the 2D area. Wang et al. [36] in this special issue establish a 3D model to quantify glaciers' 3D and 2D area differences in the Muzart Glacier catchment and in Central Tianshan using ASTER GDEM data, CGI2 and Landsat images. They found that glaciers' 3D areas was 34.2\% larger than their 2D areas in the Muzart Glacier catchment and by $27.9 \%$ in the entire Central Tianshan, where glaciers' $3 \mathrm{D}$ areas reduced by $115 \mathrm{~km}^{2}$ between 2007 and 2013, being 27.6\% larger than their 2D area reduction. This confirms that there is significantly large difference between glaciers' $3 \mathrm{D}$ and $2 \mathrm{D}$ areas in the steep Central Tianshan. As they remarked, "Those large areal differences remind us to re-consider a glacier's real topographic extent when discussing an alpine glacier's areal and volume changes, especially in calculating the glacier's surface energy balance and melting rates in the high Asian mountain glaciers with large surface slopes and strong solar radiation."

Surface soil is a critical boundary layer between atmosphere and land surface. Soil water content affects local agriculture, ecology, hydrology and climate. In the dry desert steppe, soil moisture is 
one of the main factors that control vegetation growth and ecosystem restoration. The common soil moisture measurement technologies, such as the gravimetric method, neutron method, Time Domain Reflector (TDR), Frequency Domain Reflectometry (FDR), and so on, provide point measurements with high accuracy, while being labor and time-consuming and may destroy the soil structures. Lu et al. [16] in this special issue present their study to measure the steppe soil moisture using Ground Penetrating Radar (GPR). The common-mid point (CMP) method and fixed offset (FO) method are used for sensitivity analysis, while the gravimetric soil moisture measurements are used to validate the accuracy of the GPR measurements. Their results show Topp's equation is more suitable than Roth's equation for processing GPR data in the desert steppe. Both CMP and FO methods show high accuracy in GPR soil moisture measurements. Vegetation affects the measurement precision, and precipitation reduces the effective sampling depth of the ground wave from $0.1 \mathrm{~m}$ to $0.05 \mathrm{~m}$. Overall, the operation of GPR measurements is simple and does not damage the soil layer structure, while providing high accuracy and easy movement.

Groundwater is an important freshwater resource in mid-latitude and in arid and semiarid regions. Instead of directly measuring the soil moisture or aforementioned glaciers, Li et al. [37] in this special issue used GIS and statistical tools to study the geographic distribution of land subsidence, groundwater drawdown, and compressible layer thickness using in situ monitoring data in the metropolitan areas of Beijing, the capital of China. The Beijing Plain lies in the alluvial-pluvial plain fan built up by river deposits and belongs to the temperate continental monsoon climate with annual mean temperature of $10-15^{\circ} \mathrm{C}$ and precipitation of $601 \mathrm{~mm}$. Land subsidence is one of the critical threats to the sustainable development of Beijing. Multiple approaches including point (gravity center), line (major axes), and polygon (coverage) views are tested for analyzing spatial change patterns. Results show that the Chaoyang District of Beijing had the largest land subsidence and groundwater drawdown, both of which concentration trends were consistent and the principle orientation was southwest-northeast (SW-NE). The spatial distribution pattern of land subsidence was similar to that of the compressible layer. Those results are useful for assessing the distribution of land subsidence and managing groundwater resources.

Irrigation planning is an important component in water resource and precision agriculture management. Golf courses are one kind of precision agriculture, and their turfgrass has high water demand. Turfgrass irrigation is rapidly transitioning to reuse water because of the water price incentive and mandated water management policies. Therefore, knowing the turfgrass areas and growth conditions can help plan the water and treated sewage effluent needs exactly at a daily or weekly rate. Perea-Moreno et al. [32] in this special issue utilized UAV video images to extract automatically the turfgrass areas and growth conditions by a Hierarchical Temporal Memory (HTM) algorithm, and further assess the water needs for turfgrass irrigation. The extracted turfgrass area from video imagery classification could achieve an accuracy of $98 \%$. They commented, "Technical progress in computing power and software has shown that video imagery is one of the most promising environmental data acquisition techniques available today. This rapid classification of turfgrass can play an important role for planning water management."

\subsection{Rainfall Measurements and Design Storm}

Rainfall is one of the most critical components of water cycle and water resources recharge. Heavy rainfall often causes devastating flood events. Typhoon-related heavy rainfall has unique structures in both time and space at mesoscale. Satellite rainfall estimate may better delineate the structures of heavy rainfall, which is helpful for early-warning systems and disaster management. Wang et al. [38] in this special issue compares the latest versions of two satellite rainfall products with ground rain gauge observations along the coastal region of China from 2014 to 2015. They are the GPM IMERG final run and TMPA 3B42V7. Overall, correlation coefficients (CCs) of both IMERG and TMPA with gauge observations for the eight typhoon events investigated are significant at the 0.01 level, but both TMPA and IMERG tend to underestimate the heavy rainfall against the gauge observation, 
especially around the storm center. The IMERG final run exhibits better performance than TMPA 3B42V7. In space, both products have the best applicability within the range of 50-100 km away from typhoon tracks, and the worst beyond the $300-\mathrm{km}$ range. It is always a challenging task to measure accurately heavy rainfall by rain gauges, a ground radar network, or satellite sensors.

The temporal evolution of heavy rainfall over certain area is called the storm hyetograph. Given a total rain depth and duration over a certain return period, the storm hyetograph (also called design storm) determines the peak flooding volume and is critical for drainage design in storm water management [49]. The common design storms for drainage design include the Triangular curve [50], the Chicago curve [51] and the Soil Conservation Service (SCS) curve [52]. Pan et al. [39] in this special issue compared these curves and found that they tend to underestimate the peak rainfall in the metropolitan areas of Guangzhou, south China. The normalized time of peak rainfall is at $33 \% \pm 5 \%$ for all storms in Guangzhou, and most storms (84\%) are in the 1st and 2nd quartiles. Pan et al. [39] improved the Huff curve by separately describing rising and falling limbs and then combined them into a full storm hyetograph, instead of dividing the storms into four quartiles as in the original Huff curve analysis. The improved Huff curve can better represent the storm hyetographs in Guangzhou than the other three curves. It generates larger peak flooding volumes that match better with the street water inundation depth when they are input in the Storm Water Management Model (SWMM) for given heavy storm events. "The Improved Huff curve has great potential in storm water management such as flooding risk mapping and drainage facility design, after further validation." [39].

\subsection{Rainfall Runoff Prediction and Flood Forecasting}

Hydrological models are the backbones of climatic and hydrologic simulations, water resources management, and flood forecasting. Hydrological models originated from conceptual and clumped models, and are advancing to physically-based, distributed models, such as the Gridded Surface Subsurface Hydrologic Analysis (GSSHA). Sharif et al. [40] in this special issue utilized the GSSHA model to simulate a recent flood event to gain a better understanding of the runoff generation and spatial distribution of flooding in a very arid catchment of Hafr Al Batin City, north-eastern Saudi Arabia. The GPM IMERG rainfall products (the uncalibrated early run and calibrated final run) were used to drive the GSSHA model. This showed that $85 \%$ of the flooding was generated in the urbanized portion of the catchments for the simulated flood event. Urban storm drainage and catchment runoff were used in simulations by different models. The variable model grid sizes allowed the GSSHA model to be applied on large basins that include the entire catchment for a coarse grid size and urban centers that need to be modeled at very high resolutions. Thus, urban flooding can be simulated by a single physically-based and distributed model that could model the local heavy storm runoff in the urban areas and the regional rainfall runoff on a large river catchment, and the integrated urban flooding risk can be considered at the same time.

Compared to the fine hydrologic modeling of storm runoff at grid sizes of tens of meters and minutes or hourly intervals, runoff prediction in the regional climate models (RCM) such as the Land Surface Models (LSM) is much coarser, at tens of kilometers and daily or monthly scales. The original Common Land Model (CoLM) predicts runoff from net water at each computation grid even without the explicit Lateral Flow (LF) scheme. Lee and Choi [41] in this special issue proposed a CoLM+LF model to improve the runoff prediction by incorporating a set of lateral surface and subsurface runoff computations into the existing terrestrial hydrologic processes in CoLM. The CoLM+LF model was assessed in the Nakdong River Watershed of Korea using Earth observations at the 30-km resolution and daily time step. The simulated runoff by CoLM and the CoLM+LF was then compared with the daily stream flow observations at the Jindong stream gauge station in the study watershed during 2009. CoLM+LF can simulate the effect of runoff travel time over a watershed by an explicit lateral flow scheme, and can more effectively capture seasonal variations in daily streamflow than CoLM. It is expected to be a helpful and essential tool for water resource management and hydrological impact assessment. 
Flood inundation forecast technology can generally be divided into either numerical simulation or black-box modeling. Numerical simulation is based on theoretical deduction and often has good accuracy, while demanding high computing resources and being difficult to use for the real-time forecasting of rapid disaster mitigation and rescue response in most conditions, such as during a typhoon and flash flooding. In contrast, the black-box model relies on different approaches by deeming the process from rainfall to inundation as a black box to simulate the relationship between input rainfall and output runoff and inundation [53]. It cannot explain the physical mechanism, but can correctly and effectively simulate the response after full calibration at much faster computing speed than physically-based models. Ouyang et al. [42] in this special issue proposed such a black-box model that combines non-sequential regressors for the ARX (Auto-Regressive model with eXogenous inputs)-based typhoon inundation forecast. The difficulty when using the model is finding an optimal combination of regressors to perform accurate prediction. They developed a novel approach to integrate a Multi-Objective Genetic Algorithm (MOGA) to transfer the search for the optimal combination of non-sequential regressors into an optimization problem. The results (tested in the northeastern Taiwan) showed that the optimal models acquired through this model had good inundation forecasting capabilities in terms of accuracy, time-shift error, and error distribution, thus providing practical benefits for decision making and rescue response during a typhoon landfall period.

\subsection{Water Body and Flood Mapping}

It is a challenge to forecast accurately flash flooding by hydrological models in arid regions of the Middle East like Saudi Arabia because of the sporadic storm events and scarce stream flow data. The vulnerability of arid and semi-arid regions to flash floods was thought to be similar to that of regions having heavy rain owing to the strong convective storms and the rapid formation of flash floods [54,55]. Tekeli [43] in this special issue examines the feasibility of flash flood detection over the city of Jeddah in western Saudi Arabia using TRMM TMPA Real Time (RT) 3B2RT data during 2000-2014. Three indices, constant threshold (CT), cumulative distribution functions (CDFs) and Jeddah flood index (JFI), were developed to detect flash flood events using the 3-h 3B42RT rainfall data. CDF worked best. It did not miss any flood event and had a hit rate of up to $94 \%$. Compared to hydrological models using various variables, this approach seems promising in arid regions, although only rainfall data are used.

Water surface is easily detectable by remote sensing images in most conditions because of its low reflectance, while it is a challenging task to accurately extract urban water bodies from high-resolution images due to the shadowing effect of high-rise buildings and trees. To disentangle this problem, Yang et al. [44] in this special issue proposed an automatic urban water extraction method (AUWEM) to extract urban water bodies from high-resolution ZY-3 multi-spectral images. They first refined the Normalized Difference of Water Index (NDWI) algorithm by constructing two new indices, namely NNDWI1, which is sensitive to turbid water, and NNDWI2, which is sensitive to the water body interfered with by vegetation. Both indices were then used to map all water body and shaded areas by image threshold segmentation. An object-based technology was then developed to detect the shades, which were finally removed from the classified water bodies. This automated approach was tested by five images featuring different areas and environments including lakes and rivers in the cities of Beijing, Suzhou, Wuhan and Guangzhou, China. Compared to the Maximum Likelihood Method (MaxLike) and NDWI, AUWEM had a detection accuracy of $93 \%$, against $86 \%$ for Maxlike and $89 \%$ for NDWI, and exhibited both smaller omission errors and commission errors. It even works better when detecting water edge and small rivers, and can effectively distinguish shadows of high buildings from water bodies to improve the overall accuracy.

Flood inundation mapping is similar to water body mapping, while facing more challenges, such as the short response time and cloud blockage. Flood mapping from various data sources can greatly improve disaster response, e.g., all optical images, UAV video images and radar images were 
applied in the May 2015 Texas flooding event [33]. Radar microwave images beat the optical images in flood mapping by their unique capability to penetrate through cloud. Frappart et al. [45] in this special issue use the ENVISAT ASAR images to recovery the flood extent between 2005 and 2008 in the Guayas watershed on the Pacific Coast of Ecuador, where floods are an annual phenomenon and become devastating during El Niño years. Flooded pixels present lower backscattering than bare soil or vegetation as the radar electromagnetic wave is specularly reflected by water surfaces. The core algorithm of the method is change detection using radar backscattering coefficients at the C-band between the wet and dry seasons. Mapping inundation water under tree canopy and other vegetation needs special consideration, since vegetation usually decreases the radar backscattering coefficients. In spite of the coarse spatial resolution $(1 \mathrm{~km})$ of these SAR images, the patio-temporal (monthly) dynamics of the flood in the Guayas watershed between 2005 and 2008 was mapped using ASAR images for the first time in this watershed. Moreover, other radar satellites launched in recent years, such as Sentinel-1A in April 2014, Sentinel-2A in June 2015 and Sentinel-1B in April 2016, satellite SAR (C-band) etc., can provide global coverage of flood inundation mapping every few days at unprecedented spatial resolution of tens of meters.

\section{Conclusions}

Remote sensing and GIS play critical roles in water resource and flood inundation mapping and risk management. Remote sensing provides critical data for mapping water resources (snow and glaciers, water bodies, soil moisture and groundwater), measuring hydrological fluxes (ET, precipitation and river discharge), and monitoring drought and flooding inundation; while GIS provides the best tools for water resource, drought and flood risk management and for hydrologic models' setup, input data processing, output analysis and visualization. This special issue presents the best practices, cutting-edge technologies and applications of remote sensing, GIS and hydrologic models for water resource mapping, satellite rainfall measurements, runoff and urban flood simulation, water body and flood inundation mapping, and risk management. The latest technologies applied include 3D model analysis and visualization of glaciers, UAV video image classification for turfgrass mapping and irrigation planning, ground penetration radar for soil moisture estimation, TRMM and GPM satellite rainfall measurements, storm hyetograph analysis, rainfall runoff and urban flooding simulation, and satellite radar and optical image detection for urban water bodies and flooding inundation. GIS is very versatile, but operating heroically behind the scenes at most times. GIS techniques are used in almost every paper published in this special issue for data preprocessing, spatial analysis or making results maps. The applications of those technologies are expected to greatly relieve the pressures on water resources and enable better mitigation of and adaptation to the disastrous impact of droughts and flooding.

Author Contributions: Xianwei Wang designed the article structure and wrote the manuscript. Hongjie Xie initiated the idea of this review article and revised the manuscript.

Funding: This study is funded by the Water Resource Science and Technology Innovation Program of Guangdong Province (\#2016-19).

Acknowledgments: We are grateful for being invited to be the Guest Editor for this special issue by the Water Editorial Office who set up and took care of the editorial process. We thank all the authors who contribute to this special issue. We thank the reviewers who contributed their expertise and time on reviewing those articles. Without their support, it would be impossible to assess properly those manuscripts submitted.

Conflicts of Interest: The authors declare no conflict of interest. 


\section{References}

1. Tang, Q.; Gao, H.; Lu, H.; Lettenmaier, D.P. Remote sensing: Hydrology. Prog. Phys. Geogr. 2009, 33, 490-509. [CrossRef]

2. Hall, D.K.; Riggs, G.A.; Salomonson, V.V.; DiGirolamo, N.E.; Bayr, K.J. MODIS snow-cover products. Remote Sens. Environ. 2002, 83, 181-194. [CrossRef]

3. Wang, X.; Xie, H. New methods for studying the spatiotemporal variation of snow cover based on combination products of MODIS Terra and Aqua. J. Hydrol. 2009, 371, 192-200. [CrossRef]

4. Wang, X.; Zhu, Y.; Chen, Y.; Liu, H.; Huang, H.; Liu, K.; Liu, L. Influences of forest on MODIS snow cover mapping and snow variations in the Amur River basin in Northeast Asia during 2000-2014. Hydrol. Process. 2017. [CrossRef]

5. Guo, W.; Liu, S.; Xu, J.; Wu, L.; Shangguan, D.; Yao, X.; Wei, J.; Bao, W.; Yu, P.; Liu, Q. The second Chinese glacier inventory: Data, methods and results. J. Glaciol. 2015, 61, 357-372. [CrossRef]

6. Nuimura, T.; Sakai, A.; Taniguchi, K.; Nagai, H.; Lamsal, D.; Tsutaki, S.; Kozawa, A.; Hoshina, Y.; Takenaka, S.; Omiya, S. The GAMDAM Glacier Inventory: A quality-controlled inventory of Asian glaciers. Cryosphere Discuss. 2015, 8, 849-864. [CrossRef]

7. Pfeffer, W.T.; Arendt, A.A.; Bliss, A.; Bolch, T.; Cogley, J.G.; Gardner, A.S.; Hagen, J.O.; Hock, R.; Kaser, G.; Kienholz, C.; et al. The Randolph Glacier Inventory: A globally complete inventory of glaciers. J. Glaciol. 2014, 60, 522-537. [CrossRef]

8. Aizen, V.B.; Kuzmichenok, V.A.; Surazakov, A.B.; Aizen, E.M. Glacier changes in the Tien Shan as determined from topographic and remotely sensed data. Glob. Planet. Chang. 2007, 56, 328-340. [CrossRef]

9. Kaab, A.; Berthier, E.; Nuth, C.; Gardelle, J.; Arnaud, Y. Contrasting patterns of early twenty-first-century glacier mass change in the Himalayas. Nature 2012, 488, 495-498. [CrossRef] [PubMed]

10. Pieczonka, T.; Bolch, T.; Wei, J.; Liu, S. Heterogeneous mass loss of glaciers in the Aksu-Tarim Catchment (Central Tien Shan) revealed by 1976 KH-9 Hexagon and 2009 SPOT-5 stereo imagery. Remote Sens. Environ. 2013, 130, 233-244. [CrossRef]

11. Zhang, G.; Yao, T.; Xie, H.; Kang, S.; Lei, Y. Increased mass over the Tibetan Plateau: From lakes or glaciers? Geophys. Res. Lett. 2013. [CrossRef]

12. Zhang, G.; Yao, T.; Piao, S.; Bolch, T.; Xie, H.; Chen, D.; Gao, Y.; O’Reilly, C.M.; Shum, C.K.; Yang, K.; et al. Extensive and drastically different alpine lake changes on Asia's high plateaus during the past four decades. Geophys. Res. Lett. 2017, 44. [CrossRef]

13. Entekhabi, D.; Jackson, T.J.; Njoku, E.; O’Neill, P.; Entin, J. Soil moisture active/passive (SMAP) mission concept. Proc. SPIE 2008, 70850H. [CrossRef]

14. Rodell, M.; Velicogna, I.; Famiglietti, J.S. Satellite-based estimates of groundwater depletion in India. Nature 2009, 460, 999-1002. [CrossRef] [PubMed]

15. Wang, X.; Linage, C.R.; Famiglietti, J.; Zender, C.S. Gravity Recovery and Climate Experiment detection of water storage changes in the Three Gorges Reservoir of China and comparison with in situ measurements. Water Resour. Res. 2011, 47, 1-13. [CrossRef]

16. Lu, Y.; Song, W.; Lu, J.; Wang, X.; Tan, Y. An Examination of Soil Moisture Estimation Using Ground Penetrating Radar in Desert Steppe. Water 2017, 9, 521. [CrossRef]

17. Steelman, C.M.; Endres, A.L.; Jones, J.P. High-resolution ground-penetrating radar monitoring of soil moisture dynamics: Field result, interpretation, and comparison with unsaturated flow model. Water Resour. Res. 2012, 48, 184-189. [CrossRef]

18. Wang, X.; Xie, H.; Sharif, H.; Zeitler, J. Validating NEXRAD MPE and Stage III precipitation products for uniform rainfall on the Upper Guadalupe River Basin of the Texas Hill Country. J. Hydrol. 2008, 348, 73-86. [CrossRef]

19. Wang, X.; Xie, H.; Mazari, N.; Sharif, H.; Zeitler, J. Evaluation of the near-real time NEXRAD DSP Product in the evolution of heavy rain events on the Upper Guadalupe River Basin, Texas. J. Hydroinformat. 2013, 15. [CrossRef]

20. Huffman, G.J.; Bolvin, D.T.; Nelkin, E.J.; Wolff, D.B.; Adler, R.F.; Gu, G.; Neikin, E.J.; Bowman, K.P.; Hong, Y.; Stocker, E.F.; et al. The TRMM multisatellite precipitation analysis (TMPA): Quasi-global, multiyear, combined-sensor precipitation estimates at fine scales. J. Hydrometeorol. 2007, 8, 38-55. [CrossRef] 
21. Sorooshian, S.; AghaKouchak, A.; Arkin, P.; Eylander, J.; Foufoula-Georgiou, E.; Harmon, R.; Hendrickx, J.M.H.; Imam, B.; Kuligowski, R.; Skahill, B.; et al. Advanced concepts on remote sensing of precipitation at multiple scales. Bull. Am. Meteorol. Soc. 2011, 92. [CrossRef]

22. Wang, D.S.; Wang, X.; Liu, L.; Huang, H.; Pan, C.; Wang, D.G. Evaluation of CMPA precipitation estimate in the evolution of typhoon-related storm rainfall events in Guangdong province, China. J. Hydroinform. 2016. [CrossRef]

23. Bastiaanssen, W.; Pelgrum, H.; Wang, J.; Ma, Y.; Moreno, J.; Roerink, G.; van der Wal, T. A remote sensing surface energy balance algorithm for land (SEBAL). J. Hydrol. 1998, 212-213, 198-212. [CrossRef]

24. Häuslera, M.; Conceiçãoc, N.; Tezzad, L.; Sáncheze, J.M.; Campagnolo, M.L.; Häuslerf, A.J.; Silvaa, J.M.N.; Warnekeg, T.; Heygsterg, G.; Ferreirab, M.I. Estimation and partitioning of actual daily evapotranspiration at an intensive olive grove using the STSEB model based on remote sensing. Agric. Water Manag. 2018, 201, 188-198. [CrossRef]

25. Feng, L.; Hu, C.; Chen, X.; Li, R.; Tian, L.; Murch, B. MODIS observations of the bottom topography and its inter-annual variability of Poyang Lake. Remote Sens. Environ. 2011, 115, 2729-2741. [CrossRef]

26. King, T.V.; Neilson, B.T.; Rasmussen, M.T. Estimating discharge in low-order rivers with high-resolution aerial imagery. Water Resour. Res. 2018, 54, 863-878. [CrossRef]

27. Smith, L.C.; Pavelsky, T.M. Estimation of river discharge, propagation speed, and hydraulic geometry from space: Lena River, Siberia. Water Resour. Res. 2008, 44, W03427. [CrossRef]

28. Tourian, M.J.; Sneeuw, N.; Bardossy, A. A quantile function approach to discharge estimation from satellite altimetry (ENVISAT). Water Resour. Res. 2013, 49. [CrossRef]

29. Caccamo, G.; Chisholm, L.A.; Radstock, R.A.; Puotinen, M.L. Assessing the sensitivity of MODIS to monitor drought in high biomass ecosystems. Remote Sens. Environ. 2011, 115, 2626-2639. [CrossRef]

30. Rhee, J.; Im, J.; Carbone, G.J. Monitoring agricultural drought for arid and humid regions using multi-sensor remote sensing data. Remote Sens. Environ. 2010, 114, 2875-2887. [CrossRef]

31. Wang, X.; Liu, M.; Liu, L. Responses of MODIS spectral indices to typical drought events from 20002012 in Southwest China. J. Remote Sens. 2014, 18, 433-442.

32. Perea-Moreno, A.-J.; Aguilera-Ureña, M.-J.; Meroño-De Larriva, J.-E.; Manzano-Agugliaro, F. Assessment of the Potential of UAV Video Image Analysis for Planning Irrigation Needs of Golf Courses. Water 2016, 8, 584. [CrossRef]

33. Schumann, G.J.-P.; Frye, S.; Wells, G.; Adler, R.; Brakenridge, R.; Bolten, J.; Murray, J.; Slayback, D.; Policelli, F.; Kirschbaum, D.B.; et al. Unlocking the Full Potential of Earth Observation during the 2015 Texas Flood Disaster. Water Resour. Res. 2016. [CrossRef]

34. Giustarini, L.; Chini, M.; Hostache, R.; Pappenberger, F.; Matgen, P. Flood hazard mapping combining hydrodynamic modeling and multi annual remote sensing data. Remote Sens. 2015, 7, 14200-14226. [CrossRef]

35. Wing, O.E.J.; Bates, P.D.; Sampson, C.C.; Smith, A.M.; Johnson, K.A.; Erickson, T.A. Validation of a $30 \mathrm{~m}$ resolution flood hazard model of the conterminous United States. Water Resour. Res. 2017, 53. [CrossRef]

36. Wang, X.; Chen, H.; Chen, Y. Large Differences between Glaciers 3D Surface Extents and 2D Planar Areas in Central Tianshan. Water 2017, 9, 282. [CrossRef]

37. Li, Y.; Gong, H.; Zhu, L.; Li, X. Measuring Spatiotemporal Features of Land Subsidence, Groundwater Drawdown, and Compressible Layer Thickness in Beijing Plain, China. Water 2017, 9, 64. [CrossRef]

38. Wang, R.; Chen, J.; Wang, X. Comparison of IMERG Level-3 and TMPA 3B42V7 in Estimating Typhoon-Related Heavy Rain. Water 2017, 9, 276. [CrossRef]

39. Pan, C.; Wang, X.; Liu, L.; Huang, H.; Wang, D. Improvement to the Huff Curve for Design Storms and Urban Flooding Simulations in Guangzhou, China. Water 2017, 9, 411. [CrossRef]

40. Sharif, H.O.; Al-Zahrani, M.; Hassan, A.E. Physically, Fully-Distributed Hydrologic Simulations Driven by GPM Satellite Rainfall over an Urbanizing Arid Catchment in Saudi Arabia. Water 2017, 9, 163. [CrossRef]

41. Lee, J.S.; Choi, H.I. Improvements to Runoff Predictions from a Land Surface Model with a Lateral Flow Scheme Using Remote Sensing and In Situ Observations. Water 2017, 9, 148. [CrossRef]

42. Ouyang, H.T.; Shih, S.S.; Wu, C.S. Optimal Combinations of Non-Sequential Regressors for ARX-Based Typhoon Inundation Forecast Models Considering Multiple Objectives. Water 2017, 9, 519. [CrossRef]

43. Tekeli, A.E. Exploring Jeddah Floods by Tropical Rainfall Measuring Mission Analysis. Water 2017, 9, 612. [CrossRef] 
44. Yang, F.; Guo, J.; Tan, H.; Wang, J. Automated Extraction of Urban Water Bodies from ZY-3 Multi-Spectral Imagery. Water 2017, 9, 144. [CrossRef]

45. Frappart, F.; Bourrel, L.; Brodu, N.; Riofrío Salazar, X.; Baup, F.; Darrozes, J.; Pombosa, R. Monitoring of the Spatio-Temporal Dynamics of the Floods in the Guayas Watershed (Ecuadorian Pacific Coast) Using Global Monitoring ENVISAT ASAR Images and Rainfall Data. Water 2017, 9, 12. [CrossRef]

46. Aizen, V.B.; Aizen, E.M.; Kuzmichonok, V.A. Glaciers and hydrological changes in the Tien Shan: Simulation and prediction. Environ. Res. Lett. 2007, 2, 45019. [CrossRef]

47. Cogley, J.G.; Hock, R.; Rasmussen, L.A.; Arendt, A.A.; Bauder, A.; Braithwaite, R.J.; Jansson, P.; Kaser, G.; Möller, M.; Nicholson, L. Glossary of Glacier Mass Balance and Related Terms; IHP-VII Technical Documents in Hydrology No. 86, IACS Contribution No. 2; UNESCO-IHP: Paris, France, 2011.

48. Bahr, D.B.; Meier, M.F.; Peckham, S.D. The physical basis of glacier volume-area scaling. J. Geophys. Res. Solid Earth 1997, 102, 20355-20362. [CrossRef]

49. Kang, M.S.; Goo, J.H.; Song, I.; Chun, J.A.; Her, Y.G.; Hwang, S.W.; Park, S.W. Estimating design floods based on the critical storm duration for small watersheds. J. Hydro-Environ. Res. 2013, 7, 209-218. [CrossRef]

50. Yen, B.C.; Chow, V.T. Design hyetographs for small drainage structures. J. Hydraul. Div. ASCE 1980, 106, $1055-1076$.

51. Keifer, G.J.; Chu, H.H. Synthetic storm pattern for drainage design. J. Hydraul. Div. ASCE 1957, 83, 1-25.

52. SCS. Urban Hydrology for Small Watersheds; Technical Release 55; U.S. Department of Agriculture: Washington, DC, USA, 1986.

53. Karlsson, M.; Yakowitz, S. Rainfall-runoff forecasting methods, old and new. Stoch. Hydrol. Hydraul. 1987, 1, 303-318. [CrossRef]

54. Haggag, M.; El-Badry, H. Mesoscale numerical study of quasi-stationary convective system over Jeddah in November 2009. Atmos. Clim. Sci. 2013, 3, 73-86. [CrossRef]

55. Zipser, E.J.; Cecil, D.J.; Liu, C.; Nesbitt, S.W.; Yorty, D.P. Where are the most intense thunderstorms on earth? Bull. Am. Meteorol. Soc. 2006, 87, 1057-1071. [CrossRef]

(C) 2018 by the authors. Licensee MDPI, Basel, Switzerland. This article is an open access article distributed under the terms and conditions of the Creative Commons Attribution (CC BY) license (http:/ / creativecommons.org/licenses/by/4.0/). 